\title{
PROGNOSTIC INDICES OF PATHOLOGICAL TOOTH WEAR DEVELOPMENT
}

DOI: 10.36740/WLek202007107

\author{
Svetlana A. Pavlenko, Elena V. Pavlenkova, Irina. M. Tkachenko, Alla I. Sidorova, Dmytro M. Korol \\ UKRAINIAN MEDICAL DENTAL ACADEMY, POLTAVA, UKRAINE
}

\begin{abstract}
The aim: To study possibilities of prognosis of pathological wear of tooth hard tissues development depending on the functional activity of masticatory muscles. Materials and methods: In order to achieve the goal of the study, a survey of patients at the age of 19 to 69 years was conducted for precision of number of persons who have increased tooth wear. During the examination of all patients, three groups were selected: control and two researched ones. Patients in the control group (30 patients between the age of 18 and 60 years old) had an intact dentition without any visible sign of increased tooth wear.

The researched groups included 25 patients aged from 18 to 60 years old. The second research group included patients who had increased tooth wear of I-III level. The children of the patients of the II group with or without any sign of increased tooth wear were referred to the third research group.

Results: The method of electromyography was performed for the study of peculiarities of the muscular activity of the maxillofacial area of the patients of the control and research groups. In our opinion, all manifestations of increased tooth wear are related to changes in the muscle system, the motor apparatus and the nervous activity of an organism. Conclusions: The study of direct muscular apparatus and related bone system may predict the possibility of developing of an increased tooth wear of young patients in the future and prevent its development, as well as to justify the application of a prevention and treatment plan of the studied pathology.
\end{abstract}

KEY WORDS: increased tooth wear, electromyography, tooth hard tissues, masticatory muscles

Wiad Lek. 2020;73(7):1345-1349

\section{INTRODUCTION}

Tooth wear of hard tissues of teeth is a completely natural process, which has peculiarities in patients of different age groups. In some cases it is a slow compensated process, without any disturbance of physiological functions, in others it is a progressive process accompanied by severe teeth hyperesthesia, malfunction of masticatory function, maloclusion and changes in temporomandibular joint.

The process of abrasion of enamel and dentin occurs throughout the human life, and occurs as a result of regular contact between teeth themselves and between the teeth and food during the act of mastication, which may intensify, diminish over person's life and is considered physiological. Due to the mechanical strength of the enamel and dentin, both temporary and permanent teeth wear relatively slowly and evenly [1].

In young people, tooth hard tissue abrasion is less common than in middle-aged and elderly people. Frequency and reasons of wear of hard tissues of teeth in young people depend on both endogenous and exogenous factors, which negatively affect the stability of hard tissues of teeth and determine their abrasion [2, 3]. In elderly patients the reason of tooth wear development is a partial adentia (as a consequence of pathology of occlusion), malocclusion due to incorrect prothethic treatment and functional wear of dentures [4]. In women, tooth wear is slightly less common than in men.

In studies where patients were observed for a specific period of time with constant or repeated monitoring of risk factors or health status, the researchers concluded that increased tooth wear at infancy predicts dental wear in adulthood. Insufficient development of enamel and dentin is considered to be the primary cause of tissue abrasion according to J. J. Pindborg (1970) [5].

\section{THE AIM}

To study possibilities of prognosis of pathological wear of tooth hard tissues development depending on the functional activity of masticatory muscles.

\section{MATERIALS AND METHODS}

In order to achieve the purpose of the study, a clinical examination of patients between the ages of 19 and 69 years was performed in order to identify the number of persons who have increased tooth wear. In all groups, both male and female patients were examined, who were equally matched in the groups. It should be noted that a greater number of male patients were between the ages of $40-49$, that made $20 \%$ of the total number of patients in all groups. Majority of female patients were in the age group of 20-29 years, which also made $20 \%$ of total number of patients. This distribution of patients by age was reliable and did not affect the results of our study. During the examination of all patients, three groups were selected: control and two researched. Patients in the control group 
Table 1. Electromyography results of patients from the control group $(n=30)$

\begin{tabular}{ccccc}
\hline \multirow{2}{*}{ Masseter muscles } & \multicolumn{4}{c}{ Researched parameters (M $\pm \mathbf{m})$} \\
\cline { 2 - 5 } & activity (msec.) & rest (msec.) & “K” & amplitude (mkV) \\
\hline left & $148,06 \pm 4,95$ & $152,37 \pm 4,71$ & $0,98 \pm 0,03$ & $207,58 \pm 3,38$ \\
\hline right & $135,98 \pm 3,59$ & $155,02 \pm 6,06$ & $0,91 \pm 0,06$ & $288,41 \pm 22,67$ \\
\hline
\end{tabular}

Note: $1 .{ }^{*}$ - indicators of significance level between the left and right musclesp $<0.05$;

2. $n$ is the number of patients in the group.

(30 patients between 18 and 60 years old) had an intact dentition without any visible sign of increased tooth wear.

The ground of the research was based on the results of a survey of patients of two study groups, which were divided according to family relationships and disease manifestations in order to detect genetic susceptibility to increased abrasion in probands and features of pre-manifestations and manifestations of increased tooth wear.

The research groups included 25 patients aged 18 to 60 years old. The $2^{\text {nd }}$ research group included patients with increased tooth wear of I-III stage. To the $3^{\text {rd }}$ study group the children of patients of the $2^{\text {nd }}$ study group with or without signs of increased tooth wear were attributed.

To study the peculiarities of the muscular activity of the maxillofacial area in patients of the control and researched groups, the method of electromyography was applied $[6,7,8]$.

Electromyographic studies are based on the study of the potentials of action of muscle fibers, which function in the composition of mobile units, since they are a functional unit of activity of the neuromuscular apparatus $[9,10]$.

For the myogram record a two-channel myograph M-440 company «Medicor», computer and printer were used. The record was carried out in the following mode: -calibration signal; - calmness; - jaw compression; - arbitrary mastication; - swallowing.

Such a program was used for examination of patients of all groups.

All electromyograms were analyzed by qualitative and quantitative indicators $[8,9]$.

Evaluating qualitative indicators, we take in the account the presence or absence of activity during the rest, the nature of the excitation force at maximal closure of the jaws, the breakdown of the record structure, the unilateral or sequential nature of chewing, the uniform alternation of periods of bioelectric activity and rest of the muscles.

Quantitative data processing with the elements of variational statistics according to Student-Fisher was carried out using a computer program, which provided the definition of the following parameters:

- oscillation amplitudes (minimum and maximum, in $\mu \mathrm{V}$ ), which characterize the excitation force and the number of motor units involved in muscle contraction;

- time of activity, as an indicator of concentration in the time of the process of excitation, rest - an indicator of the concentration of brake processes and one dynamic cycle (msec.);

- coefficient «K» - an indicator of the ratio of the processes of excitation and inhibition in each dynamic cycle - «activity» - «rest» $[7,9]$.
For comparison of the obtained data the indicators of the control group were used, which correspond to the norma according to studies $[10,11,12]$.

The idea of the state of masticatory muscles in patients with increased tooth abrasion and the nature of chewing function recovery can be created only on the basis of data on the nature of movements of masticatory muscles, their tone and bioelectric activity $[8,9,10]$.

According to the purpose of the study, we received electromyograms in the control group with intact dental rows and in the patients of the researched groups before treatment.

\section{RESULTS}

Patients from the control group were examined on the qualitative and quantitative characteristics of the bioelectric activity of masticatory muscles.

In an electromyographic study of patients in the control group a functional test of «arbitrary mastication» was applied.

The intact dentition is characterized by the fact that the amplitude of the biocurrents on the working side is higher than on the balancing.

We paid attention to the main indices that characterize mastication in the researched patients, namely: activity of bioelectric volleys, rest time, activity factor " $K$ " and amplitude of electromyogram. All these parameters were statistically processed using the Microsoft Excel.

Quantitative and statistical processing of electromyograms of control group persons are presented in the tab. 1

Analyzing the electromyogram digital data of control group we noticed that the activity and rest times of both the left and right masseter muscles are almost indistinguishable.

The activity of the left masseter was $148.06 \pm 4.95 \mathrm{msec}$, while the right one was $135.98 \pm 3.59 \mathrm{msec}$. The rest time of the left masseter was $152.37 \pm 4.71 \mathrm{~ms}$ and the right muscle was $155.02 \pm 6.06 \mathrm{~ms}$.

It is noteworthy that the $\mathrm{K}$ activity factor for the left and right masseter muscles differs, respectively, at $0.98 \pm 0.03$ and $0.91 \pm 0.06$, but this difference is not significant and indicates an absence of functional asymmetry.

There is a significant difference in left and right masseter muscle amplitude. The amplitude of the left one is 207.58 $\pm 3.38 \mu \mathrm{V}$, while the right one is only $288.41 \pm 22.67 \mu \mathrm{V}$. This may indicate a more active movement of the right masseter muscle than the left one. 

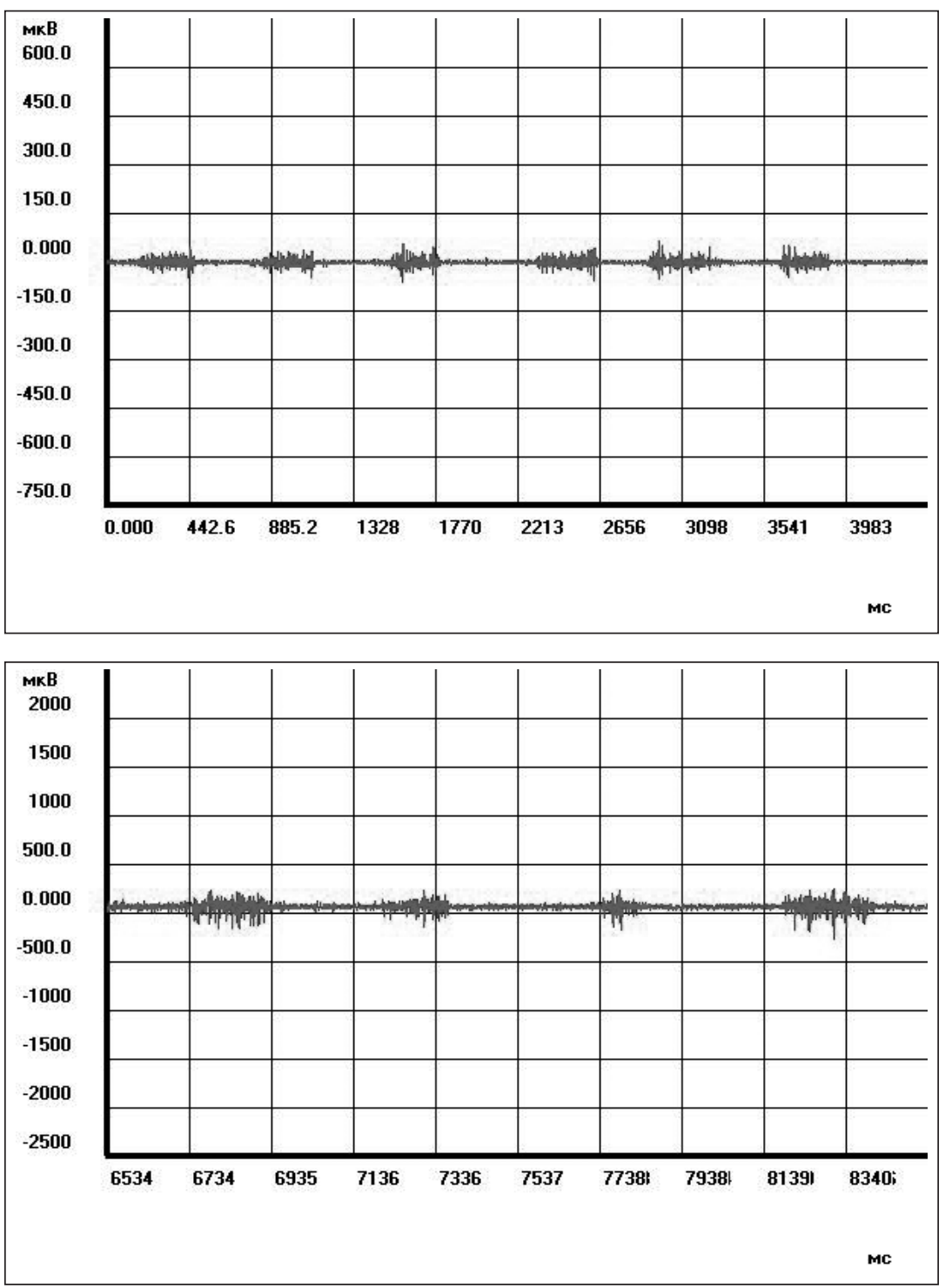

Fig. 1. Fragment of an electromyogram of the left masseter muscle of a patient 56years old before treatment (2nd group).

Fig 2. Fragment of an electromyogram of the left masseter muscle of a patient, 32 years old, before treatment (group 3)

Table 2. Electromyography results of patients 2 nd group $(n=25)$ before treatment

\begin{tabular}{|c|c|c|c|c|c|}
\hline \multirow[b]{2}{*}{ Group } & \multirow[b]{2}{*}{ Masseter muscle } & \multicolumn{4}{|c|}{ Parameters $(\mathbf{M} \pm \mathbf{m})$} \\
\hline & & activity(mser.) & $\begin{array}{c}\text { rest } \\
\text { (mser.) }\end{array}$ & “K” & $\begin{array}{l}\text { amplitude } \\
\text { (мкВ) }\end{array}$ \\
\hline \multirow{4}{*}{$2(n=25)$} & \multirow{2}{*}{ left } & 226,1 & 327,46 & 0,71 & 383,45 \\
\hline & & $\pm 24,89$ & $\pm 22,84$ & $\pm 0,049$ & $\pm 42,41$ \\
\hline & \multirow{2}{*}{ right } & 266,79 & 267,21 & 0,83 & 452,96 \\
\hline & & $\pm 58,69$ & $\pm 35,16$ & $\pm 0,060$ & $\pm 32,59$ \\
\hline
\end{tabular}

Notes: 1. ${ }^{*}$ - indicators of significance level between the left and right muscles, $p<0.05$;

$2 . n$ is the number of patients in the group.

Therefore, it can be concluded that, when performing masticatry movements, the muscles are capable to activate themselves instantly and transit rapidely to rest stage equally. The data obtained show that the muscles on both sides are not equally involved in the act of mastication and differ in functional asymmetry.

Indicators of electromyographic studies $2^{\text {nd }}$ and $3^{\text {rd }}$ research groups are different from the control group. In our opinion, this fact indicates a decrease in mastication efficiency due to the pathology of the hard tissues of the teeth and a decrease in the height of the occlusion (Fig. 1, Fig. 2).

The results of the analysis of electromyograms of the second and third research groups of patients with increased tooth wear of I-III stage are presented in table. 2 and table. 3. Children of patients from the $2^{\text {nd }}$ group who have had with or without signs of increased tooth wear were included to the $3^{\text {rd }}$ group.

Comparing to the control group, the electromyography indices in the third group also differ on the left and right 
Table 3. Electromyography results of patients from the 3rd group $(n=25)$ before treatment

\begin{tabular}{|c|c|c|c|c|c|}
\hline \multirow[b]{2}{*}{ Groups } & \multirow[b]{2}{*}{ Masseter muscle } & \multicolumn{4}{|c|}{ Parameters $(M \pm m)$} \\
\hline & & Activity (msec.) & $\begin{array}{c}\text { rest } \\
\text { (msec.) }\end{array}$ & “K” & $\begin{array}{l}\text { amplitude } \\
(\mathrm{mkV})\end{array}$ \\
\hline \multirow{2}{*}{$\begin{array}{c}3 \\
(n=25)\end{array}$} & left & $\begin{array}{c}215,47 \\
\pm 3,88\end{array}$ & $\begin{array}{l}296,16 \\
\pm 14,75 \\
\end{array}$ & $\begin{array}{c}0,79 \\
\pm 0,081\end{array}$ & $\begin{array}{c}294,64 \\
\pm 2,48\end{array}$ \\
\hline & right & $\begin{array}{l}279,18 \\
\pm 31,95\end{array}$ & $\begin{array}{l}285,07 \\
\pm 32,31 \\
\end{array}$ & $\begin{array}{c}1,11 \\
\pm 0,09 \\
\end{array}$ & $\begin{array}{l}354,43 \\
\pm 36,69\end{array}$ \\
\hline
\end{tabular}

Notes: 1. * indicators of a significance level between the left and right muscles, $p<0.05$;

$2 . n$ is the number of patients in the group.

sides (Fig. 2), but this difference is much smaller than in the patients of the second group (Tab.3).

In the 3 rd group the coefficient of masticatory activity of the left masseter muscle was slightly higher comparing to the $2^{\text {nd }}$ group $(0.79 \pm 0.081$ vs $0.71 \pm 0.049)$. In $3^{\text {rd }}$ group, the activity coefficient of the right masseter muscle is much higher than in the $2^{\text {nd }}$ group ( $1.11 \pm 0.09$ vs $0.83 \pm 0.06$ respectively) and the activity indicators of rest stage are slightly lower in the left master muscle in comparison to the right one.

Thus, the activity of the left masseter muscle in the 3rd group is $215.47 \pm 3.88 \mathrm{~ms}$, while the right one is 279.18 $\pm 31.95 \mathrm{~ms}$.

The indices of the rest stage of left masseter muscle in the $3^{\text {rd }}$ group were $296.16 \pm 14.75 \mathrm{~ms}$, while the right ones were $285.07 \pm 32.31 \mathrm{~ms}$.

It should be mentioned that the values of the amplitude of masseter muscles in the $3^{\text {rd }}$ group are slightly lower than the corresponding indices in the $2^{\text {nd }}$ group. Thus, the values of the amplitude of the left and right masseters in the $3^{\text {rd }}$ group are respectively $294,64 \pm 2,48$ and $354,43 \pm$ $36.69 \mu \mathrm{V}$. These rates are significantly lower than the corresponding data obtained from the patients of the $2^{\text {nd }}$ group.

Therefore, we suppose that differences in the electromyography parameters of $2^{\text {nd }}$ and $3^{\text {rd }}$ groups are related to the different degree of manifestation of increased tooth wear and malfunction of mastication.

All the manifestations of increased tooth wear, in our opinion, are related to changes in the system of muscles, motor apparatus and nervous activity of the body. Regarding to this, the study of the direct muscular apparatus and the related bone system may suggest the possibility of developing pathological wear of teeth of young patients in the future and prevent its development, as well as justify the use of a plan for the prevention and treatment of researched pathology.

\section{CONCLUSIONS}

Based on the results of our study, we can conclude that the study of the functional condition of the muscular complex is a reliable prognostic sign in the study of such a disease as an increased wear of hard tissues of teeth and is a reliable prognostic criterion for predicting the development of pathological abrasion of teeth of young patients in the future.

\section{REFERENCES}

1. Kravchenko D. 0. Nauchnoe obozrenie. Meditsinskie nauki [Scientific review. Medical sciences]. 2017, no. 3, pp. 39-42. (In Russian).

2. Fedorov Yu. A., Drozhzhina V. A. Klinicheskaya stomatologiya: rukovodstvo dlya vrachey [Clinical dentistry: guidelines for physicians]. Moscow: Meditsinskaya kniga, 2010, pp. 241-272. (In Russian).

3. Giri B. T., Shivlinga B. M., Jyothikiran H. Morphological and Dentoalveolar Evaluation of Jaws using Cephalometry. Moscow: LAP Lambert Academic Publishing, 2012, 76 p. (In Russian).

4. Iordanishvili A. K., Yankovskiy V. V., Serikov A. A. Kurskiy nauchnoprakticheskiy vestnik «Chelovek i ego zdorov'e» [Kursk scienctific and practical bulletin "People and their health"]. 2014; (2) 33-40. (In Russian).

5. Pindborg J. J. Pathology of the dental hard tissues. Copenhagen: Munksgaard, 1970. (In English).

6. Georgiev V.I. Elektromiograficheskoe izuchenie funktsii zhevatelnyih myishts cheloveka pri intaktnom ortognaticheskom prikuse: avtoref. dis. na soiskanie uchen. stepeni kand. med. nauk: spets. 14.01.22 "Stomatologiya» [Electromyographic study of the function of the chewing muscles of a person with an intact orthognathic bite]. K.; 1969. 19. (In Russian).

7. Lebedenko I.Yu. Funktsionalnyie i apparaturnyie metodyi issledovaniya v ortopedicheskoy stomatologii [Functional and instrumental methods of research in orthopedic dentistry]. In: Lebedenko I.Yu., Ibragimov T.I., eds. M.: MIA; 2002: 125. (In Russian).

8. Tkachenko I. Doslidzhennya funktsionalnoho stanu zhuval'nykh myaziv u normi elektromiohrafichnym metedom. [Research of the functional state of masticatory muscles in normal electromyographic method] Ukrainian Dental Almanac. 2012; 55-7. (In Ukrainian).

9. Malyuchenko M.M. Reografichil ta elektromiografichni pokazniki pri ortopedichnomu likuvanni patologichnoyi stertosti zubiv u osib starshih vikovih grup [Rheographic and electromyographic indices during orthopedic treatment of pathological dental rubbing of persons of older age groups] Ukrayinskiy stomatologichniy almanah. 2001;3-4:36-38.( In Ukrainian).

10. Pavlenko S., Pavlenkova E., Tkachenko I., Sidorova A., Vodoriz Y. Changes in the functional condition of the masticatory muscles with increased teeth abrasion. Wiadomości Lek. 2019; 72 (5):1002-6.

11. Vodoriz Y., Marchenko I., Shundryk M., Tkachenko I. Review of treatment methods of patients with uncomplicated teeth fractures Wiadomosci Lek. 2018; 71 (7): 1360-64.

12. Tkachenko I., Kovalenko V., Skrypnikov P., Vodoriz Y Reasoning of adhesive system choice for treatment of patients with increased tooth wear. Wiadomosci Lek. 2018; 71 (6): 1129-34. 
The study is a fragment of research and development of the Ukrainian Medical Stomatological Academy "Morphofunctional features of oral cavity tissues and their influence on the performance of treatment activities and the choice of treatment materials" - registration number 01145 U001112.

\section{ORCID and contributionship:}

Svetlana A. Pavlenko: 0000-0001-5657-0959 A,B

Elena V. Pavlenkova: 0000-0002-3106-1231 ${ }^{\mathrm{C}}$

Irina M. Tkachenko: 0000-0001-8243-8644 ${ }^{D}$

Alla I. Sidorova: 0000-0001-8131-3495 ${ }^{\mathrm{E}}$

Dmytro M. Korol: 0000-0002-8331-0500 ${ }^{F}$

\section{Conflict of interest:}

The Authors declare no conflict of interest

\section{CORRESPONDING AUTHOR}

\section{Elena V. Pavlenkova}

Ukrainian Medical Dental Academy

23 Shevchenko st. 36000 Poltava, Ukraine

tel: +380503041806

e-mail: Pavlenkovaev@ukr.net

Received: 07.03.2020

Accepted: 18.06 .2020

A - Work concept and design, B - Data collection and analysis, C - Responsibility for statistical analysis,

D-Writing the article, $\mathbf{E}$-Critical review, $\mathbf{F}$ - Final approval of the article 